\title{
Two new species of Apocynaceae, Asclepiadoideae from Mayotte
}

\author{
W. Douglas Stevens, Jean-Noël Labat ${ }^{\dagger} \&$ Fabien Barthelat
}

\begin{abstract}
STEVENS, W.D., J.-N. LABAT \& F. BARTHELAT (2016). Two new species of Apocynaceae, Asclepiadoideae from Mayotte. Candollea 71: 127-134. In English, English and French abstracts. DOI: http://dx.doi.org/10.15553/c2016v711a15

Two new species endemic to Mayotte are described and illustrated: Marsdenia mayottae W.D. Stevens, Labat \& Barthelat and Tylophora mayottae W.D. Stevens, Labat \& Barthelat (Apocynaceae, Asclepiadoideae). Marsdenia mayottae is similar to Marsdenia vohiborensis Choux from Madagascar but differs by its very small or sometimes absent corona. Tylophora mayottae is morphologically close to Tylophora coriacea Marais but differs by its much smaller flowers. These two new species, discovered in during recent inventories, are assessed as threaten following the Categories and the Criteria of the IUCN Red List.
\end{abstract}

\section{Résumé}

STEVENS, W.D., J.-N. LABAT \& F. BARTHELAT (2016). Deux nouvelles espèces d'Apocynaceae, Asclepiadoideae de Mayotte. Candollea 71: 127-134. En anglais, résumés anglais et français. DOI: http://dx.doi.org/10.15553/c2016v711a15

Deux nouvelles espèces endémiques de Mayotte, Marsdenia mayottae W.D. Stevens, Labat \& Barthelat et Tylophora mayottae W.D. Stevens, Labat \& Barthelat (Apocynaceae, Asclepiadoideae), sont décrites et illustrées. Marsdenia mayottae est similaire à Marsdenia vohiborensis Choux mais en diffère par sa couronne très réduite, parfois absente. Tylophora mayottae est morphologiquement proche de Tylophora coriacea Marais dont il se distingue par des fleurs beaucoup plus petites. Ces deux nouvelles espèces, découvertes à la suite d'inventaires récents, sont évaluées comme menacées selon les Catégories et les Critères de la Liste rouge de l'UICN.

\section{Keywords}

APOCYNACEAE - ASCLEPIADOIDEAE - Marsdenia - Tylophora - Comoros - Mayotte

\footnotetext{
Addresses of the authors:

WDS: Missouri Botanical Garden, P.O. Box 299, St. Louis, MO, 63166-0299, U.S.A. E-mail: stevens@mobot.org

JNL: Muséum national d'Histoire naturelle, rue Buffon 16, 75005 Paris, France.

FB: DEAL, Service Ressources Naturelles, Pole Biodiversité, B.P. 54, 97102 Basse-Terre cedex, Guadeloupe. 


\section{Introduction}

Between 1995 and 1998, an intensive inventory of the plants of Mayotte (a French territory in the Comoro Archipelago), concentrated mainly on trees and shrubs, was conducted by the Service de l'Environnement et de la Forêt of Mayotte (SEF), in collaboration with the Herbarium of the Muséum national d'Histoire naturelle in Paris (MNHN). This initial inventory was followed in 2000 by a threeyear multidisciplinary project "Interactions entre espèces à Mayotte, variations de la biodiversité et des valeurs patrimoniales perçues", which was funded by the French "Ministère de l'Ecologie et du Développement Durable" as part of its "Programme Ecosystèmes Tropicaux". One of the objectives of this project was to complete an inventory of the flowering plants of the island, which was carried out by MNHN and SEF. Following these projects, a permanent inventory programme was developed by SEF and initiated in 2007 by the Conservatoire Botanique National de Mascarin. Together, these efforts have substantially increased the number of specimens available from the island, whose flora was previously known almost entirely from material gathered in the XIXth century (for details of collectors who worked in Mayotte and elsewhere in the Comoros, see Dorr, 1997).

Mayotte, like the other islands of the Comoro Archipelago, is characterized by a high level of modification of the natural vegetation. On Mayotte, little-disturbed primary forest occupies no more than $18.48 \mathrm{~km}^{2}$ representing only about $5 \%$ of the $354 \mathrm{~km}^{2}$ of the main island (PASCAL et al., 2001; PAscal, 2002). Recent collections include many species never before recorded from the island, some of which are not known from elsewhere in the Comoros. More than 20 new species have been described to date, based primarily on the material generated by the recent inventory efforts, including in the following families and genera: Acanthaceae (Anisotes Nees - Daniel, 2014), Achariaceae (Erythrospermum Lam. - Hul et al., 1999), Araliaceae (Polyscias J.R. Forst. \& G. Forst. - Lowny et al., 1999), Asteraceae (Psiadia Jacq. ex Willd. - Labat \& Beentje, 2004), Boraginaceae (Hilsenbergia Tausch ex Meisn. Miller, 2003), Dioscoreaceae (Dioscorea L. - Wilkin et al., 2007), Fabaceae-Caesalpinioideae (Cynometra L. - LABAт \& Pascal, 1999), Lecythidaceae (Foetidia Comm. ex Lam. Labat et al., 2011), Malvaceae (Nesogordonia Baill.; LABAT et al., 2001), Melastomataceae (Memecylon L. - Stone, 2006), Myrtaceae (Eugenia L. and Syzygium Gaertn. - Byng et al., 2016), Olacaceae (Olax L. - Rogers et al., 2006), Oleaceae (Noronbia Thouars and Chionanthus L. - LABAT et al., 1999), Passifloraceae (Adenia Forssk. - Pignal et al., 2013), Putranjivaceae (Drypetes Vahl. - McPherson, 2000), Rutaceae (Ivodea Capuron and Vepris Comm. ex A. Juss. - LABAt et al., 2005 ; Rabarimanarivo et al.,
2015), Salicaceae (Scolopia Schreb. - Hul et al., 1999) and Sapotaceae (Labramia A. DC. - LabAT et al., 1997). Study of the material of Apocynaceae revealed two new species that are described here, both are Asclepiadoideae, one a Marsdenia $\mathrm{R}$. Br. and the other a Tylophora R. Br. Both of the new species are provided with line drawings, discussions of their morphology and preliminary risk of extinction assessments following IUCN Red List Categories and Criteria (IUCN, 2012).

\section{Taxonomy}

Marsdenia mayottae W.D. Stevens, Labat \& Barthelat, spec. nova (Fig. 1, 2).

Typus : Mayotte: Grande Terre, Bandrélé, Rassi Abambo, 9.II.2001, Barthelat, M'Changama \& Ali Sifari 295 (holo: P [P00229277]!; iso: G!, K!, MAO!, MO!, P [P00282507]!).

Marsdenia mayottae W.D. Stevens, Labat $\&$ Barthelat is most similar to M. vohiborensis Choux, but differs from this species by its umbonate style apex completely covered by the terminal anther appendages and the absence or near absence of a corona.

Shrub or twining vine, woody but apparently not corky, underground parts unknown, stems densely appressedpuberulent, sparsely lenticellate, internodes 1-6 cm; latex white. Leaves opposite; blades 6.5-11.1 $\times 4-9.2 \mathrm{~cm}$, ovate to elliptic, glabrous or puberulent on veins below; apex acuminate to attenuate; base truncate to shallowly lobate, its sinus up to $5 \mathrm{~mm}$ deep, lateral veins 4 to 6 , colleters 10 to 24 ; petiole $2.4-5.5 \mathrm{~cm}$, sparsely puberulent. Inflorescences solitary, paniculate with 2 to 6 congested-racemose, appressedpuberulent branches; peduncle (3) $10-48 \mathrm{~mm}$; fertile axes up to $3 \mathrm{~cm}$ long, more or less covered with pedicel scars. Flowers borne on pedicels 4-9 $\mathrm{mm}$ long; bracts numerous and conspicuous, $1.5-10 \times 0.6-4 \mathrm{~mm}$, elliptic to spathulate, sometimes leaf-like; calyx with 1 colleter below each sinus within, lobes elliptic to ovate with round tips, unequal, 3-4 $\times 1.7-2 \mathrm{~mm}$, sparsely puberulent along axis abaxially, not ciliolate, green ; corolla shallowly campanulate, dull yellow, without calli, barbate in distal half of tube and proximal half or more of each lobe adaxially, glabrous abaxially, tube $1.7-2.3 \mathrm{~mm}$, lobes elliptic with tip rounded, $2.2-3 \times 1.6$ $1.7 \mathrm{~mm}$, patent; corona lobes absent or if present reduced to a fleshy tooth adnate to base of anther, deltate, up to $0.4 \mathrm{~mm}$ long, $0.2 \mathrm{~mm}$ wide at base; gynostegium nearly sessile, guide rails $0.7 \mathrm{~mm}$ long, slightly salient at base; anthers trapezoidal, nearly rectangular, $0.8-1 \times 0.8-1 \mathrm{~mm}$, terminal appendages $0.6 \times 0.6 \mathrm{~mm}$, elliptic to ovate, translucent, corpusculum ellipsoid to subsagittoid, $0.19-0.28 \times$ 0.08-0.13 mm, translators flat, $0.19-0.25 \times$ ca. $0.05 \mathrm{~mm}$, pollinia ellipsoid to obovoid, $0.39-0.43 \times 0.24-0.3 \mathrm{~mm}$; 


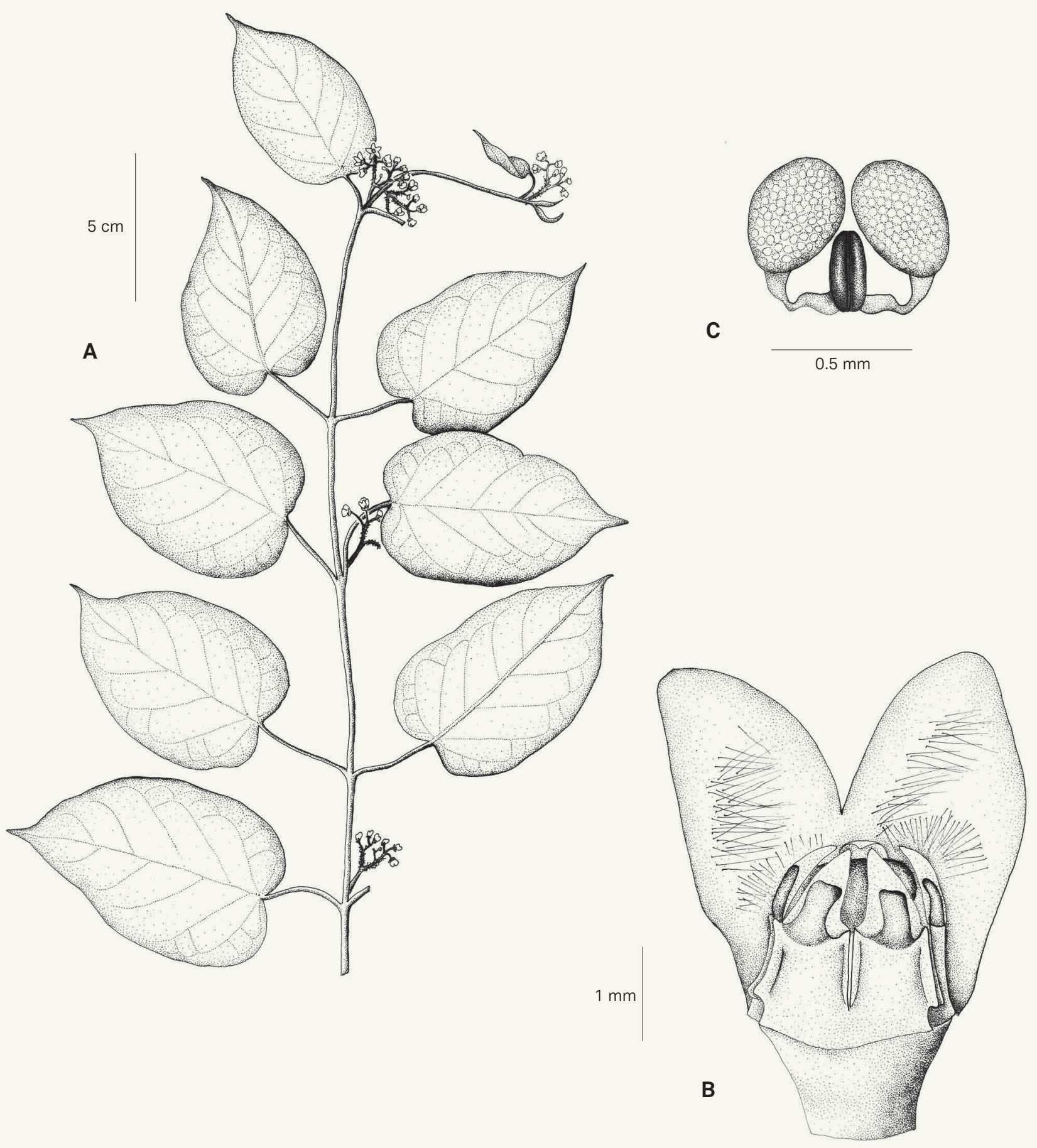

Fig. 1. - Marsdenia mayottae W.D. Stevens, Labat \& Barthelat. A. Habit; B. Gynostegium; C. Pollinarium. [Barthelat et al. 295, P] [Drawing: A. Arbeláez] 


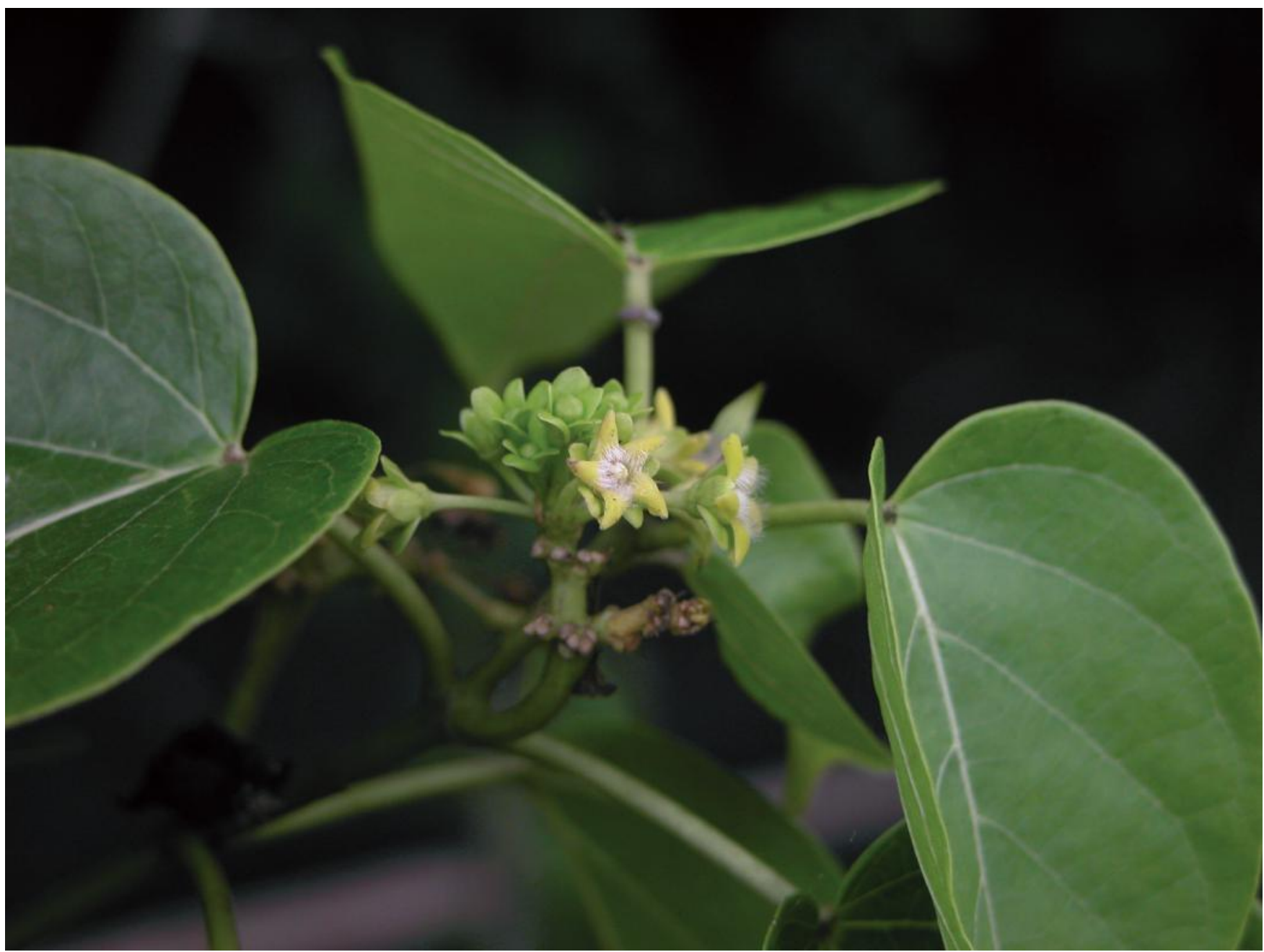

Fig. 2. - Field pictures of the new species Marsdenia mayottae W.D. Stevens, Labat \& Barthelat. [Photos: F. Barthelat]

style apex umbonate, 1.4-1.5 mm wide at base. Follicles narrowly ovoid with asymmetrical base, 7.5-9.5 × 2.5-3.5 cm, smooth, glabrous, follicle wall 5-7 mm thick; seeds elliptic, 8-11 $\times 5-7 \mathrm{~mm}$, dark grey-brown with red-brown mottling, margin $0.6-0.7 \mathrm{~mm}$ wide, distally entire or inconspicuously crenulate, surface smooth, coma $3.5-4 \mathrm{~cm}$ long, white.

Distribution, habitat and phenology. - Marsdenia mayottae is only known from Mayotte, where it can be found at low elevations (less than $10 \mathrm{~m}$ a.s.1.) in littoral forest growing with Thespesia populnea (L.) Sol. ex Corrêa, Xylocarpus granatum Koenig, Mimusops comorensis Engl., Maytenus undata (Thunb.) Blakelock and Calophyllum inophyllum L. It is also found on coastal squeletic soils on basaltic rock or in dry littoral scrubland with Grewia picta Baill., G. triflora (Bojer) Walp., Guettarda speciosa L. and Maytenus undata.
In addition, it can be found also on calcareous sand soil with Talipariti tiliaceum (L.) Fryxell. The new species is very rarely present also in dry lowland forest on other substrates at up to $100 \mathrm{~m}$.

Marsdenia mayottae has been recorded in flower from November to January and in fruit in May and June.

Vernacular names and local use. - The following vernacular names in Shibushi have been recorded for M. mayottae by Barthelat \& Boullet (2005) or on herbarium labels: "Pamba suisui be" or "Pamba suisui famakitrano", "Macarangana vahi", "Vahy rotono", "Vahy maro" and "Kidoro voalavo". The plants are used in the preparation of magic potions known as "grigris" (M. M'changama, pers. comm.). 


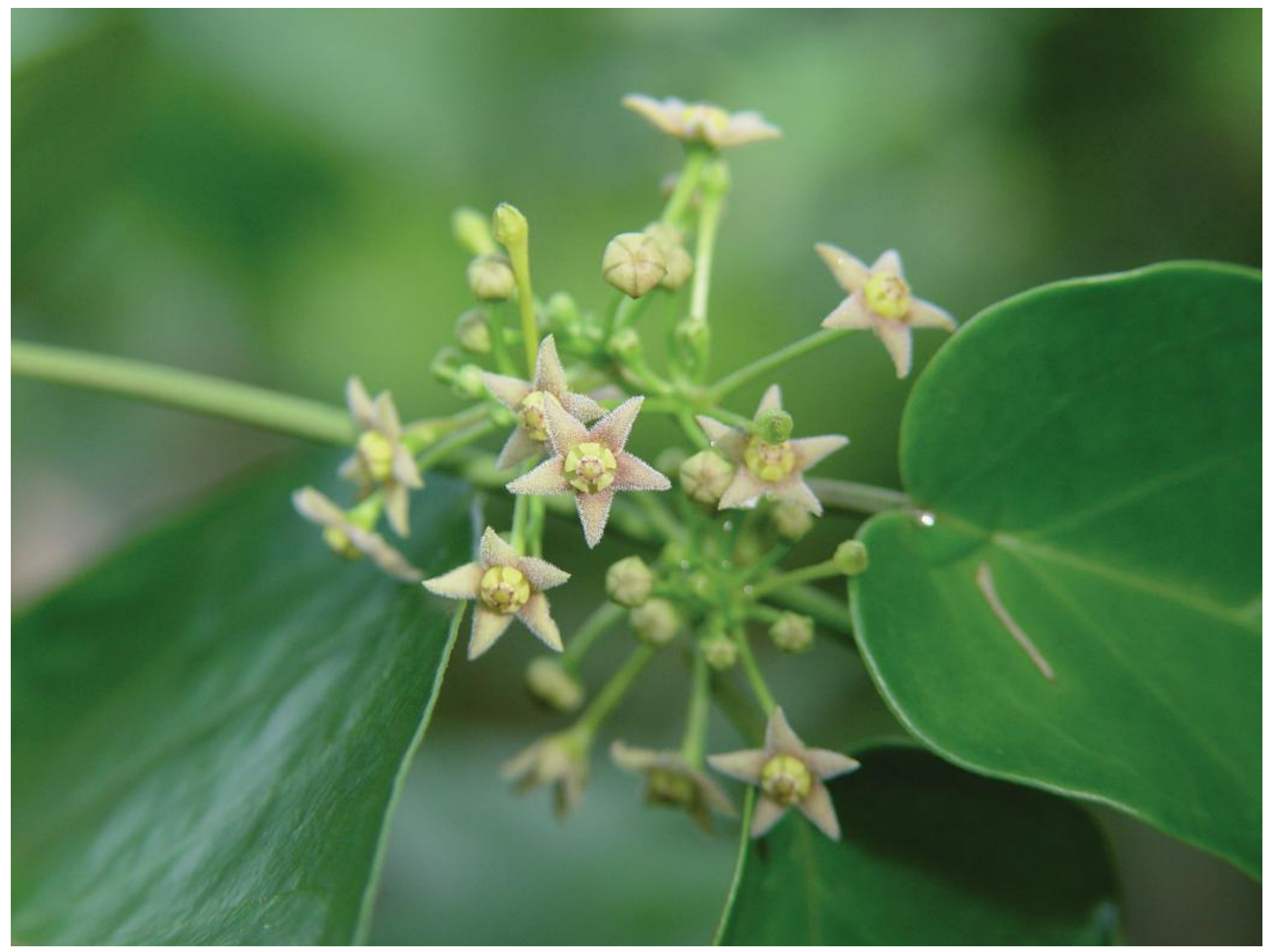

Fig. 3. - Field pictures of the new species Tylophora mayottae W.D. Stevens, Labat \& Barthelat. [Photos: F. Barthelat]

Conservation status. - Marsdenia mayottae is only known from highly threatened littoral and lowland dry forests on Mayotte, and its population, as currently known, is highly fragmented. It is only known from five locations despite intensive inventories in the last decades. Thus, its preliminary risk of extinction can be assessed as "Endangered" [EN B2ab(iii)] following the IUCN Red List Categories and Criteria (IUCN, 2012).

Notes. - This species shares a dense, bracteate inflorescence with $M$. vobiborensis Choux from the central plateau of Madagascar. However, $M$. vohiborensis has a long-exserted style apex while M. mayottae has an umbonate style apex completely covered by the terminal anther appendages. The absence or near absence of a corona in M. mayottae is unique among the species of Marsdenia of Madagascar and the Comoros, and rare in the genus.
Paratypi. - MayotTe: Grande Terre, Saziley, 17.I.2001, Barthelat E Ali Sifari 233 (G, K, MAO, MO, P); Petite Terre, Labattoir, Plage de Moya, 15.I.2002, Barthelat \& Ali Sifari 694 (K, MAO, MO, P); ibid. loc., 15.I.2002, Barthelat \& Ali Sifari 699 (MAO, MO, P); Grande Terre, Mliha, Mtsumbatsu, 20.XII.2001, Barthelat et al. 625 (MAO, MO, P); sommet du Bouzi, X.1850, Boivin s.n. (P); Rassi Maoussi, 17.V.1999, Mas 176 (P); Sohoa, 28.VI.1997, Pascal 942 (G, MO, P).

Tylophora mayottae W.D. Stevens, Labat \& Barthelat, spec. nova (Fig. 3, 4).

Typus: MAYoTTE: Grande Terre, Mamoudzou, réserve forestière de Majimbini, La Convalescence, 5.IX.2001, Barthelat et al. 483 (holo-: P [P00229464]! iso-: BR!, K!, MAO!, MO!).

Tylophora mayottae W.D. Stevens, Labat $\mathcal{E}$ Barthelat is similar to T. coriacea Marais, but with smaller flowers which are rotate and a shorter corolla tube $(0.2-0.5 \mathrm{~mm})$ and with guide rails which are shorter $(0.15-0.2 \mathrm{~mm})$. 
Twining and trailing vine with white latex. Stems rooting at nodes, woody and corky below, with hirsutulous indument present at the nodes and sometimes extending in a continuous line along the internodes; internodes 3-14 cm long. Leaves opposite; blades 6.7-13.5 $\times 4-8.8 \mathrm{~cm}$, ovate to elliptic, apex acute to acuminate, base obtuse to truncate or shallowly lobed with a sinus up to $7 \mathrm{~mm}$ deep, both surfaces glabrous, glossy, succulent, margin thickened, lateral veins 4 to 6 , colleters 2 to 10 , sometimes raised on a fleshy pad; petioles $0.7-3.4 \mathrm{~cm}$, glabrous or hirsutulous on the upper side. Inflorescence 4.5$6.0 \mathrm{~cm}$ long, with hispidulous indument forming a continuous line on the axis; peduncle $1.7-2.2 \mathrm{~cm}$ when in flower, up to $5.3 \mathrm{~cm}$ long when in fruit. Flowers borne on pedicels $0.5-$ $0.6 \mathrm{~cm}$ long; bracts $2.2 \times 0.3 \mathrm{~mm}$, linear to lanceolate; calyx apparently without colleters, lobes 1.3-1.3 $\times$ $0.5 \mathrm{~mm}$, lanceolate, apex acute, glabrous or with a few hairs on midrib and margin; corolla pale pink, glabrous outside, densely white-hispid inside with hairs $0.15 \mathrm{~mm}$ long, tube $0.2-0.5 \mathrm{~mm}$, lobes $2-2.5 \times 1-1.2 \mathrm{~mm}$, lanceolate with acute apex; corona pale yellow $1.0 \mathrm{~mm}$ high, 1.5-1.6 $\mathrm{mm}$ in diam., 5-lobed; lobes free, erect, more or less reaching to the base of anthers, apices rounded; corpusculum narrowly ellipsoid, 0.2-0.22 × 0.07$0.08 \mathrm{~mm}$, translators $0.09 \mathrm{~mm}$ long, pollinia ellipsoid, $0.18-0.2 \times 0.14-0.16 \mathrm{~mm}$; ovaries glabrous. Follicles $8.2 \times$ $1.1 \mathrm{~cm}$, narrowly fusiform, glabrous, smooth, green; seeds 10-11 $\times 5.5-6.5 \mathrm{~mm}$, dark brown, margin $0.8 \mathrm{~mm}$ wide, irregularly toothed on distal third, surface smooth, finely hispidulose on both sides; coma $2-2.5 \mathrm{~cm}$ long, white.

Distribution, habitat and phenology. - Tylophora mayottae is only known from Mayotte, it has been recorded in sub-humid to humid forest between 200 to $400 \mathrm{~m}$ in the Majimbini and Combani forest reserves on Grande Terre and in the coastal forests at Saziley on Grande Terre and at Moya on Petite Terre. It has been recorded in flower in October and November, and in mature fruit in September, but flowering and fruiting probably spans at least from August to December.

Vernacular names and local use. - The new species is known from data recorded by BARTHELAT \& Boullet (2005) or on herbarium labels as "Vahy rountou", "Vahy rotono be" or "Pamba suisui be" in Shibushi dialect, and "Ouvamba suisui bole" in Shimaore dialect. The plant is used in the preparation of magic potions known as "grigris" (M. M'changama pers. comm.).

Conservation status. - Tylophora mayottae is rare and clearly has a restricted distribution. It is known from only three recent collections from three separate protected areas, and three collections from the XIXth century, two of which have no locality details other than "Mayotte". The preliminary risk of extinction of Tylophora mayottae is therefore assessed as "Vulnerable" [VU D2] following the IUCN Red List Categories and Criteria (IUCN, 2012). Further information on the extant population is needed to be able to provide a more reliable assessment of the conservation status of the new species.

Notes. - Tylophora mayottae is vegetatively similar to T. coriacea, which is restricted to Mauritius, Reunion and the Seychelles, but differs from it by its smaller flowers which are rotate (vs. subcampanulate), with a shorter corolla tube $(0.2-0.5$ vs. $1.7-2 \mathrm{~mm})$ and shorter guide rails $(0.15-0.2$ vs. 0.6-0.8 mm).

In a recent molecular study (Liede-Schumann et al., 2012), Tylophora and a variety of other tropical genera were placed in synonymy with the north-temperate genus Vincetoxicum Wolf. However the authors are not convinced of the merits of this view, and prefer to maintain the genus Tylophora as distinct until more compelling evidence is available.

Paratypi. - MayotTE: Grande Terre, Bandrélé, Saziley, La Convalescence, 30.IX.2003, Barthelat et al. 1242 (P); Grande Terre, Bandrélé, Saziley, La Convalescence, 29.XI.2005, Barthelat et al. 1526 (P); sine loc., Boivin s.n. (P); sine loc., XI.1850, Boivin 3210 (K, P) ; forêt de Combani, 21.X.1884, Humblot 1336 (K, P).

\section{Acknowledgements}

The authors would like to thank Ali Bacar Sifari and Maoulida M'Changama for their help on the field in Mayotte and Alba Arbeláez, who produced the line drawings. The authors would also like to thank an anonymous reviewer for its constructive comments on an earlier version of this manuscript and Martin Callmander and Peter Phillipson for their help in finalizing this manuscript. This paper is dedicated to Jean-Noël Labat (1959-2001) who stimulated this paper and worked tirelessly in developing botanical projects in Mayotte and the Comoros, but who passed away on January $9^{\text {th }}$ 2011. Jean-Noël worked in a number of countries over his career, had seemingly boundless energy, and for many years was a friendly and helpful presence in the sometimes daunting MNHN in Paris.

\section{References}

Barthelat, F. \& V. Boullet (2005). Index de la flore vasculaire de Mayotte - version 2005-1. In: Rolland, R., V. Boullet \& J.-P. Quod (ed.), Mayotte: Biodiversité et Evaluation Patrimoniale: 115-187. DAF de Mayotte \& CBN Mascarin.

Byng, J.W., F. Barthelat, N. Snow \& B. Bernardini (2016). Revision of Eugenia and Syzygium (Myrtaceae) from the Comoros archipelago. Phytotaxa 252: 163-184. 

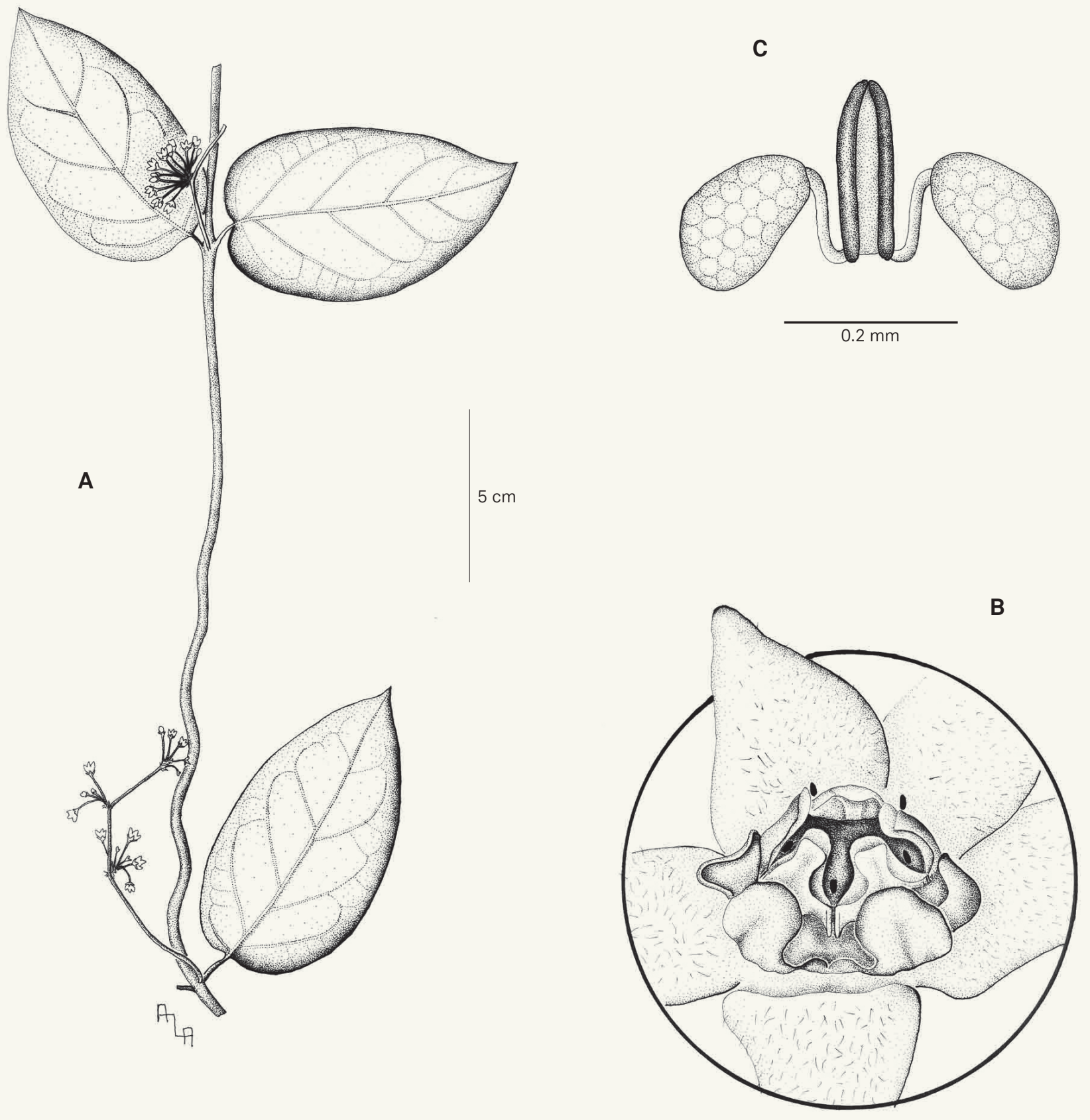

Fig. 4. - Tylophora mayottae W.D. Stevens, Labat \& Barthelat A. Habit; B. Gynostegium; C. Pollinarium. [Boivin 3210, P] [Drawing: A. Arbeláez] 
Daniel, T.F. (2014). Taxonomy of Anisotes Nees (Acanthaceae: Justicieae) in the Comoros Archipelago and a preliminary list of Acanthaceae in the Islands. Candollea 69: 45-54.

Dorr, L. (1997). Plant collectors in Madagascar and the Comoro Islands. Royal Botanic Gardens, Kew.

Hul, S., J.-N. Labat \& O. Pascal (1999). Deux nouvelles espèces de Flacourtiaceae de l'Ile de Mayotte dans l'Archipel des Comores. Adansonia ser. 3, 20:263-269.

Humbert, H. (ed.) (1960). Psiadia. Fl. Madagascar Comores 189(1): 267-311.

Labat, J.-N. \& H. Beentje (2004). A new species of Psiadia (Compositae) from Mayotte. Kew Bull. 58: 971-975.

Labat, J.-N., E. Bidault \& G. Viscardi (2011). Une nouvelle espèce de Foetidia (Lecythidaceae, sous-famille Foetidioideae) en danger critique d'extinction récemment découverte à Mayotte, archipel des Comores. Adansonia ser. 3, 33: 263-269.

Labat, J.-N., J. Munzinger \& O. Pascal (2001). Une nouvelle espèce de Nesogordonia Baill. (Sterculiaceae) de Mayotte, Archipel des Comores. Candollea 55 : 293-296.

Labat, J.-N. \& O. Pascal (1999). Two new species of Cynometra (Fabaceae: Caesalpinioideae) from Mayotte in the Comoro Archipelago. Kew Bull. 54: 163-169.

Labat, J.-N., M. Pignal \& O. Pascal (1997). Une nouvelle espèce de Labramia (Sapotaceae) de l'Ile de Mayotte dans l'Archipel des Comores. Adansonia ser. 3, 19:213-216.

Labat, J.-N., M. Pignal \& O. Pascal (1999). Trois espèces nouvelles d'Oleaceae et note sur la présence d'Olea capensis dans l'Archipel des Comores. Novon 9: 66-72.

Labat, J.-N., M. Pignal \& O. Pascal (2005). Deux espèces nouvelles et une combinaison nouvelle chez les Rutaceae de l'Archipel des Comores. In: Keating, R.C., V. Hollowell \& T.B. Croat (ed.), A Festschrift for William G. D'Arcy: the legacy of a taxonomist. Monogr. Syst. Bot. Missouri Bot. Gard. 104: 361-369.

Liede-Schumann, S., H. Kong, U. Meve \& M. Thiv (2012). Vincetoxicum and Tylophora (Apocynaceae: Asclepiadoideae: Asclepiadeae) - two sides of the same medal: Independent shifts from tropical to temperate habitats. Taxon 61: 803-825.
Lowry, P.P. II, O. Pascal \& J.-N. Labat (1999). A new species of Polyscias (Araliaceae) from Mayotte, Comoro Islands. Adansonia ser. 3, $21: 67-73$.

Marais, W. (1985). Notes on Mascarene Asclepiadaceae. Kerw Bull. 40: 205-207.

McPherson, G. (2000). Drypetes (Euphorbiaceae) in Madagascar and the Comoro Islands. Adansonia ser. 3, 22: 205-209.

Miller, J. (2002). A revision of Ehretia (Boraginaceae) for Madagascar and the Comoro Islands. Adansonia ser. 3, 24: 137-157.

Pascal, O., J.-N. Labat \& M. Pignal (2001). Diversité, affinités phytogéographiques et origine présumée de la flore de Mayotte (Archipel des Comores). Syst. Geogr. Pl. 71 : 1101-1123.

Pascal, O. (2002). Plantes et forêts de Mayotte. Patrimoines Naturels 53. Muséum national d'Histoire naturelle, Paris.

Pignal, M., R. Yockteng, D.J. Hearn \& J.-N. Labat (2013). Adenia barthelatii (Passifloraceae), a new endemic species of Mayotte and its phylogenetic status within the genus Adenia. Phytotaxa 99: 40-48.

Rabarimanarivo, M.N., N.H. Rakotonirina, P.B. Phillipson, P.P. Lowry II, J.-N. Labat \& M. Pignal (2015). Révision du genre Ivodea Capuron (Rutaceae), endémique de Madagascar et de l'archipel des Comores. Adansonia ser. 3, 37: 63-102.

Rogers, Z.S., V. Malécot \& K.G. Sikes (2006). A synoptic revision of Olax L. (Olacaceae) in Madagascar and the Comoro Islands. Adansonia ser. 3, 28: 71-100.

Stone, R.D. (2006). New species of Memecylon L. and Warneckea Gilg (Melastomataceae) from Madagascar and Mayotte. Adansonia ser. 3, 28: 337-358.

Wilkin, P., A. Hladik, J.-N. Labat \& F. Barthelat (2007). A new edible yam (Dioscorea L.) species endemic to Mayotte, new data on D. comorensis R. Knuth and a key to the yams of the Comoro Archipelago. Adansonia ser. 3, 29: 215-228. 